\title{
Administration of probiotic sanolife Mic-S on biological performance of Vanamei Shrimp (Litopenaeus vannamei) PL 10
}

\author{
Hasim $^{1}$, Nadia Baidi ${ }^{1}$, Syamsuddin ${ }^{1}$, Rully Tuiyo ${ }^{1}$ \\ ${ }^{1}$ Department of Aquaculture, Faculty of Fisheries and Marine Sciences, State University \\ of Gorontalo \\ e-mail : hasim@ung.ac.id
}

\begin{abstract}
Vannamei shrimp is a fishery commodity that has important economic value for Indonesia. This is indicated by the increasing number and value of exports of this commodity. One of the efforts to encourage the production of vaname shrimp is through the use of probiotics. sanolife-MIC is a probiotic widely used in shrimp culture. The aim of the study was to analyze the feed profile and biological performance of Vaname PL 10 shrimp fed pellets with the Sanolife MIC-S probiotic capsule at different doses. The research method used is an experimental method using a completely randomized design (CRD) with four treatments (A: probiotic $0 \mathrm{gr} / \mathrm{kg}$ feed; B: probiotic $10 \mathrm{gr} / \mathrm{kg}$ feed; C: probiotic 12 $\mathrm{gr} / \mathrm{kg}$ feed; D: probiotic $14 \mathrm{~g} / \mathrm{kg}$ feed) and three replicates. What was tested in the study were probiotic profile tests, growth, feed efficiency and feed conversion. The data obtained were analyzed using ANOVA. The results showed that the feed profile that was encapsulated using sanolife MIC-S, the protein value, moisture content and ash content for the feed were shown by treatment $\mathrm{B}$. The best fat content was treatment $\mathrm{C}$. The best crude fiber content was treatment $\mathrm{D}$. Weight growth rate, ratio The best feed conversion and feed efficiency was shown by treatment B, while the length growth and survival was indicated by treatment $\mathrm{C}$. Keywords: Vannamei Shrimp, Probiotics, Growth, and Survival.
\end{abstract}

\section{Introduction}

Vaname Shrimp (Litopenaeus vannamei) is a leading commodity in several countries in the world, including Indonesia. Therefore, Indonesia makes Vaname Shrimp as the main export commodity of the fisheries sector. Indonesia is even the 4th largest shrimp exporter in the world after India, Vietnam and Ecuador (FAO 2017).

Vaname Shrimp cultivation is very developed because this species has advantages. Vannamei shrimp have high adaptability to environmental factors such as temperature and salinity. Then this type of shrimp has a good acceptance of commercial feed (Adiwijaya and Sumantri, 2008).

The development of shrimp farming has pushed the need for commercial feed to increase. On the one hand, commercial feed is the largest component in aquaculture production costs, which can reach 60\% (Heptarina et al. 2010). Feed is one of the main components in cultivation to obtain high growth and survival. However, feeding with high protein content has the potential to cause pollution. Because not all of the feed given is effectively consumed by the shrimp. On the other hand, only part of it is able to be assimilated by the shrimp body (Febrianti et al. 2010). Furthermore, the rest will be toxic compounds such as ammonia and 
nitrite. Therefore, it is necessary to give probiotics to maintain water quality so that it can increase the production of vaname shrimp.

Probiotics are live microorganisms that are provided in sufficient quantities for environmental health and shrimp growth. According to (Verschuere et al. 2000) and (Nayak 2010) probiotics have a positive influence in improving environmental quality and improving nutrition as well as increasing immune responses. Thus, the provision of probiotics in cultivation will encourage the growth of bacteria that can act as bioremediation. Besides, it controls the growth of pathogenic bacteria.

According to Herdianti et al. (2015) bacteria found in probiotics have a role in degrading toxic chemical compounds, accelerating the nutrient cycle process, thereby controlling disease attacks. According to Hapsari et al. (2016) the provision of probiotics in feed was proven to increase the growth rate and production of shrimp.

According to Irianto (2003) probiotics can control pathogenic bacteria in the intestines through enzymes released so that the process of digestion of food. Furthermore, it was explained that groups of probiotic bacteria include Bacillus sp, Photobacterium sp, Lactobacillus sp. Meanwhile, Jusadi (2004) stated that Bacillus $\mathrm{sp}$. has the ability to produce and optimize protase enzymes.

In larval culture systems, especially from the Post Larva (PL) stage, there is a large accumulation of ammonia and nitrite in the water column due to high density and feces. The accumulation of these compounds is a limiting factor in the production system (Banerjee et al. 2010). This condition is often anticipated by changing the water. However, it has the potential to cause eutrophication in its natural environment (Ziemann et al. 1992). Cultivation systems with the addition of probiotics, water exchange can be reduced or even eliminated, because probiotics act on the absorption and decomposition of organic matter in water and sediment, which improves water quality (Wang et al. 2007).

Sanolife MIC-S is a probiotic from INVE Aquaculture that can inhibit the growth of pathogens, can help the process of natural waste decomposition, produce strong Post Larvae, increase the growth and survival of Shrimp. Various studies on the probiotic Sanolife MIC - S have been carried out, one of which is a study (Corteel et al. 2013) which succeeded in reducing the mortality of shrimp larvae. Nune (2016) conducted research on tilapia seeds. The results obtained indicate that each treatment has a very significant effect. All previous research, the treatment of sanolife probiotics was given directly in the rearing water media. There is no research that examines the application of mixed sanolife in shrimp feed. Based on the description, the aim of the study was to analyze the biological performance of post-vaname shrimp larvae given the sanolife probiotic mixed in their feed.

\section{Methods}

Research activities have been carried out at the Marine and Brackish Cultivation Development Center, Boalemo Regency, Gorontalo Province. The research method used is experimental. The study used a completely randomized design with four treatments and three replications. The containers used for the aquarium are 12 units, each filled with $50 \mathrm{~L}$ of water with 1 fish/liter. Treatment A 
$=$ Probiotic $0 \mathrm{~g} / \mathrm{kg}$ commercial feed (Control), Treatment $\mathrm{B}=$ Probiotic $10 \mathrm{~g} / \mathrm{kg}$ commercial feed, Treatment $\mathrm{C}=$ Probiotic $12 \mathrm{~g} / \mathrm{kg}$ commercial feed, Treatment $\mathrm{D}=$ Probiotic $14 \mathrm{~g} / \mathrm{kg}$ commercial feed. Sanolife MIC-S probiotics with a certain dose are dissolved in water as much as $100 \mathrm{ml} / 1 \mathrm{~kg}$ of feed and then aerated for 12 - 24 hours then the probiotics are put into a spray bottle after which they are sprayed evenly on the feed and the feed is dried for 30 minutes then the feed is ready to use. The test shrimp were fed four times per day at 07.00, 13.00, 19.00 and 01.00 WITA as much as $25 \%$ of the mass weight of the tested shrimp. Proximate analysis of each treatment was carried out at the Bogor Agricultural University Biotechnology laboratory. Water quality analysis is carried out directly in-situ consisting of temperature, $\mathrm{pH}$, salinity, and dissolved oxygen.

\section{Data Analysis}

a. Absolute weight growth

Analysis of absolute weight growth refers to the formulation of $\mathrm{Hu}$ et al. (2008) namely:

$$
P B M=W t-W o
$$

Description:

PM: Absolute growth (g)

Wt: Final weight $(\mathrm{g})$

Wo: Initial weight (g)

b. Absolute length growth

The analysis of absolute length growth refers to the formula proposed by

Cholik et al. (2005)

Description:

$$
P P M=L t-L o
$$

Lt: final length (mm)

Lo: Initial length of the experiment $(\mathrm{mm})$

c. Life sustainability

Survival Rate analysis based on the formulation proposed by Effendi (1997), namely:

$$
S R=\frac{N t}{N o} x 100 \%
$$

Description:

SR: Survival Rate (\%)

Nt: Number of t-th shrimp (tail)

No: Number of shrimps at the beginning of the experiment (tail)

d. Feed Efficiency

The feed efficiency analysis follows the formulation presented by Watanabe (1988) as follows

$$
E P=\frac{(W t+D)-W o}{F} x 100 \%
$$


Discription:

$\mathrm{EP}=$ Feed efficiency

$\mathrm{Wt}=$ Shrimp biomass at time $\mathrm{t}(\mathrm{g})$

Wo $=$ Shrimp biomass at the beginning of the experiment $(\mathrm{g})$

$\mathrm{D}=$ Weight of shrimp that died during rearing $(\mathrm{g})$

$\mathrm{F}=$ Amount of Feed given $(\mathrm{g})$

e. Feed Conversion Ratio

The feed conversion ratio was calculated based on the formulation presented by Zonneveld et al., (1991) as follows.

Discription:

$$
R K P=\frac{F}{W t-W o}
$$

RKP: Feed conversion ratio

F: Amount of feed given $(\mathrm{g})$

Wt: Shrimp biomass at time $\mathrm{t}(\mathrm{g})$

Wo: Shrimp biomass at the beginning of the experiment $(\mathrm{g})$

The data obtained were then analyzed using Analysis of Varience (ANOVA) with SPSS 26 application with a confidence level (0.05).

\section{Results and discussion}

\section{Protein Profile Pellets In Sanolife MIC-S Capsules}

The results of the pellet profile test in the sanolife MIC-S probiotic capsule can be seen in the following table.

Table 1. Protein profile of pellets encapsulated by sanolife probiotic MIC-S

\begin{tabular}{|c|c|c|c|c|c|c|}
\hline No. & $\begin{array}{c}\text { Sample } \\
\text { code }\end{array}$ & $\begin{array}{c}\text { Water } \\
\text { Cadre (5) }\end{array}$ & Abu (\%) & Fat (\%) & $\begin{array}{c}\text { Protein } \\
(\%)\end{array}$ & $\begin{array}{c}\text { Coarse } \\
\text { Fiber (\%) }\end{array}$ \\
\hline 1. & $\begin{array}{c}\mathrm{A}(0 \mathrm{gr} \\
\text { probiotics) }\end{array}$ & & & & 50.00 & \\
\hline 2. & $\begin{array}{c}\text { B (10 } \\
\text { grams of } \\
\text { probiotics) }\end{array}$ & $\begin{array}{c}15.69- \\
15.99\end{array}$ & $\begin{array}{c}16.34- \\
16.65\end{array}$ & $\begin{array}{c}5.27- \\
5.34\end{array}$ & $\begin{array}{c}53.57- \\
53.95\end{array}$ & $\begin{array}{c}18.75- \\
19.18\end{array}$ \\
\hline 3. & $\begin{array}{c}\text { C (12 } \\
\text { grams of } \\
\text { probiotics) }\end{array}$ & $\begin{array}{c}15.67- \\
16.48\end{array}$ & $\begin{array}{c}16.43- \\
16.83\end{array}$ & 4.79 & $\begin{array}{c}52.10- \\
52.76\end{array}$ & $\begin{array}{c}17.36- \\
18.66\end{array}$ \\
\hline 4. & $\begin{array}{c}\mathrm{D}(14 \\
\text { grams of } \\
\text { probiotics) }\end{array}$ & $\begin{array}{c}16.01- \\
16.33\end{array}$ & $\begin{array}{c}16.44- \\
16.57\end{array}$ & $\begin{array}{c}5.13- \\
5.84\end{array}$ & $\begin{array}{c}50.50- \\
50.75\end{array}$ & $\begin{array}{c}17.82- \\
18.18\end{array}$ \\
\hline
\end{tabular}


The protein profile of pellets encapsulated by sanolife MIC-S probiotics shows that the use of the right dose can increase nutrition in the feed. Based on the table, the test results showed that the highest protein content value was indicated by treatment B (probiotic $10 \mathrm{~g} / \mathrm{kg}$ feed) which was 53.57-53.95\%. In the body's energy-producing activities, protein is the main nutrient needed. Shrimp need for protein content is very large to be able to grow. Shrimp need protein content in feed of around 46-54\% for optimal growth (Yuwono, 2005). The average protein requirement for shrimp is $39.8-45.6 \%$, for vaname it is 30 or $>36 \%$ (Rosyta, 2006). The protein content of each feed used is still in the range of $50-53.95 \%$. This feed is considered to be able to increase the growth and survival of fish more quickly.

Fat is very important for the growth and survival of shrimp, fat is one source of energy that the body needs to be absorbed into an energy source. The fat content in the feed used ranged from 4.79-5.84\%. The low fat content in treatment $\mathrm{C}$ (probiotic $12 \mathrm{~g} / \mathrm{kg}$ feed) was thought to be caused by the addition of probiotics. Microbes in probiotics in the form of Bacillus sp. which are lipolytic can produce lipase which will convert fat into fatty acids and glycerol (Rahman et al. 2018).

Crude fiber is a food ingredient that cannot be absorbed, this material can come from plants and does not undergo breakdown during the digestive process either mechanically or with the help of digestive enzymes (Rahmat et al. 2018). Crude fiber content in the feed ranged from 17.36-19.18\%. The smaller the value of crude fiber in the feed, the better the feed is absorbed. The best value of crude fiber was found in treatment D (probiotic $14 \mathrm{~g} / \mathrm{kg}$ feed).

Moisture content plays an important role in maintaining feed quality. Feed that has a high water content will trigger biological activity in the feed and the entry of spoilage bacteria which can cause the feed to spoil quickly (Rahmat et al. 2018). The water content of the feed used is in the range of 15.67-16.33\%. The increase in water content in the feed is thought to be due to the addition of probiotics. So that the need for a drying process again so that the feed does not rot quickly. A good water content for feed is no more than $10 \%$ (Rahmat et al. 2018). The best water content was in treatment B (probiotic $10 \mathrm{~g} / \mathrm{kg}$ feed), because it had the lowest water content.

Ash content is a mixture of inorganic or mineral components contained in a food. The lowest ash content was shown by treatment B (probiotic $10 \mathrm{~g} / \mathrm{kg}$ feed). The ash content in the feed used ranged from 16.34-16.83\%. One of the causes of the increase in ash content in feed is due to microbes. The less organic matter is degraded, the relatively less there is a proportional decrease in ash content, on the contrary, the more organic matter is degraded, the relatively more there is a proportional increase in ash content, in general. feed does not contain levels of no more than $13 \%$ (Rahmat et al. 2018). 


\section{Vaname Shrimp Biological Performance}

\section{Weight Growth of Vannamei Shrimp (Litopenaeus vannamei)}

The results of the absolute weight measurement of Vaname Shrimp (Litopenaeus vannamei) can be seen in the image below.

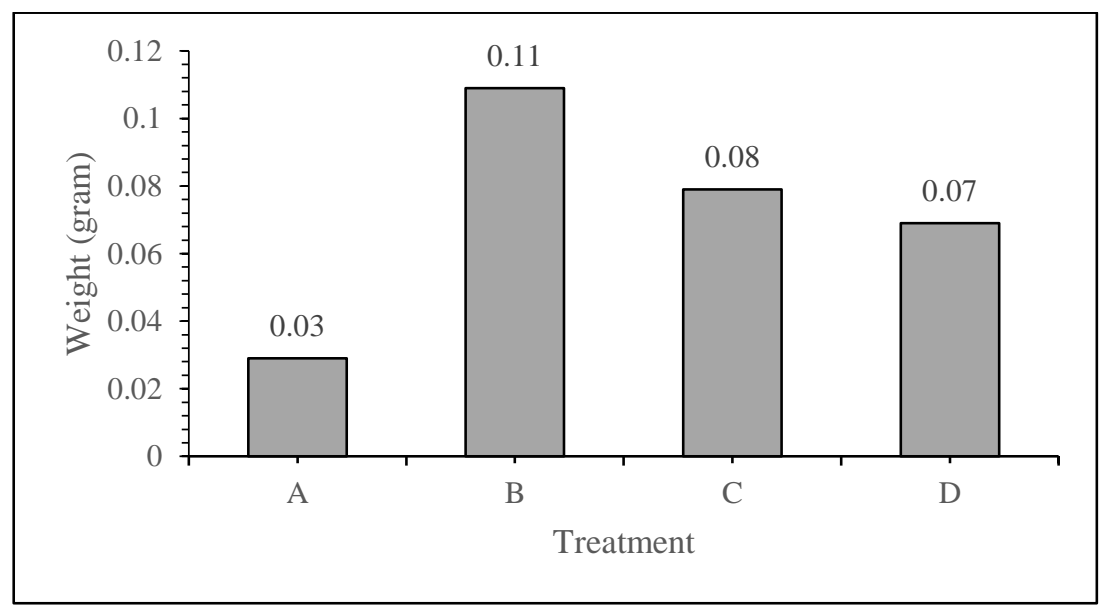

Figure 1. Graph of Weight Growth Results

The absolute growth graph above shows the effect of the use of the probiotic Sanolife MIC-S on the weight growth of vaname shrimp. In the graph it can be seen that the best weight growth rate is in treatment B (probiotic $10 \mathrm{~g} / \mathrm{kg}$ feed) where the growth rate reaches $0.11 \mathrm{~g}$. The lowest growth was shown in treatment $\mathrm{A}$ (control $0 \mathrm{~g} / \mathrm{kg}$ feed) which only reached $0.03 \mathrm{~g}$.

The high growth rate in treatment $\mathrm{B}$ was thought to be due to the addition of sanolife MIC-S probiotic at a dose of $10 \mathrm{~g} / \mathrm{kg}$ of feed gave a good response to good biological performance for vannamei shrimp post larvae compared to others, the dose of probiotics in treatment $\mathrm{B}$ was able to optimize the digestive system in shrimp post larvae, where probiotics containing sanolife MIC-S containing lactobacillus bacteria can help the process of food absorption and increase appetite for vaname shrimp post larvae so that shrimp growth becomes faster.

The addition of probiotics at a dose of $10 \mathrm{~g} / \mathrm{kg}$ of feed can improve the performance of digestive enzymes so that they can trigger optimal growth (Wang 2007). The use of probiotics can trigger an increase in shrimp immunity and can assist in the absorption of feed nutrients into the body, thereby triggering the growth of cultured shrimp (Basir, 2013). Feed that is encapsulated using probiotics can improve feed quality (Malik, 2008). Feed that has been added with probiotics can improve the response of vannamei shrimp very well to feed so that it can trigger faster growth (Syadillah et al. 2020).

The slow growth of vannamei shrimp in treatments C (12 g/kg feed) and D (14 $\mathrm{g} / \mathrm{kg}$ feed) was thought to be because these two doses were taken too much so that it had a negative impact on the vannamei shrimp growth. The use of the right dose of probiotics can optimize the absorption of shrimp to feed nutrients, thus triggering faster shrimp growth (Usman and Rochmady 2017). Shrimp growth is also influenced by size, stocking density, age, rearing container and digestibility of feed 
(Effendi 2003). To determine the effect of the performance of the probiotic dose on the growth of feeding weight, it can be seen in the following ANOVA test table. Table 2 . The results of the ANOVA test on the weight growth of vaname shrimp.

\begin{tabular}{lrrrrr}
\hline & Sum of Squares & df & Mean Square & F & Sig. \\
\hline Between Groups & .009 & 3 & .003 & 34.762 & .000 \\
Within Groups & .001 & 8 & .000 & & \\
\hline Total & .010 & 11 & & & \\
\end{tabular}

The results of the ANOVA test in the table above show that the weight growth of vanname shrimp larvae fed with the sanolife MIC-S probiotic encapsulated feed had a significant effect ( $\mathrm{Sig}<0.05$ ). so that the decision taken is to accept $\mathrm{H} 1$ and reject $\mathrm{H} 0$.

\section{Long Growth Vaname Shrimp (Litopenaeus vannamei)}

The results of measuring the growth of white shrimp (Litopanaeus vannamei) can be seen in the following figure.

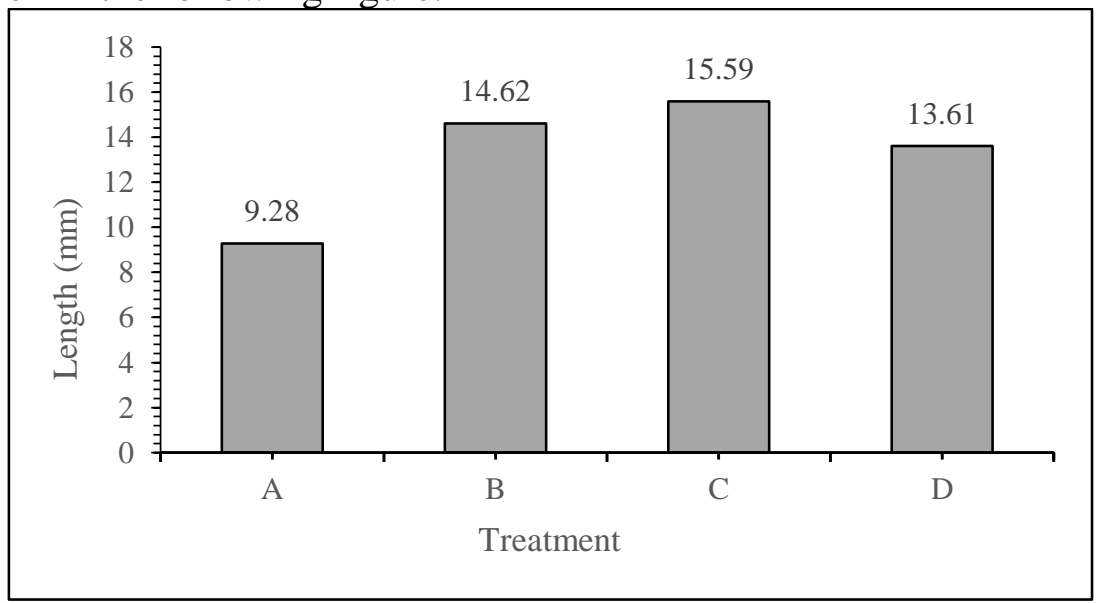

Figure 2. Graph of long growth results

The graphic above shows that the first and second absolute length growth rates were shown by treatments $\mathrm{C}$ and $\mathrm{B}$, where the absolute length growth rates reached $15.59 \mathrm{~mm}$ and $16.62 \mathrm{~mm}$, respectively. The lowest length growth was shown by treatment A which only reached $9.28 \mathrm{~mm}$. The increased growth of post larval shrimp in treatment $\mathrm{C}$ compared to treatment $\mathrm{A}$ was possible because of the contribution of the dose of sanolife MIC-S probiotics that was given so that it helped in the absorption of nutrients in the feed, especially protein, and also the use of probiotics was considered able to increase the nutritional value of the feed.

The use of probiotics added to feed can increase growth, because probiotics themselves can increase the nutritional value of feed (Widarnani et al. 2008). The addition of probiotics in the feed will produce cellulolytic and amylolytic enzymes that can increase growth (Tahe et al. 2011). The growth of vaname shrimp will be faster with rearing using probiotics, compared to those that do not use probiotics (Fernando 2016). To determine the effect of the performance of the probiotic dose on the growth of feeding length, it can be seen in the following ANOVA test table. 
Table 3. The results of the analysis of variance of ANOVA on the length growth of vaname shrimp.

\begin{tabular}{lrrrrr}
\hline & Sum of Squares & df & Mean Square & F & Sig. \\
\hline Between Groups & 70.276 & 3 & 23.425 & 10.272 & .004 \\
Within Groups & 18.245 & 8 & 2.281 & & \\
\hline Total & 88.521 & 11 & & & \\
\hline
\end{tabular}

The results of the ANOVA test in the table show that the length growth of vaname shrimp post larvae fed with sanolife MIC-S probiotic capsules with different doses had a significant effect ( $\mathrm{Sig}<0.05$ ). So that the decision taken is to accept $\mathrm{H} 1$ and reject $\mathrm{H} 0$.

\section{Life sustainability}

The results of observations of the survival rate of vaname shrimp during the rearing period can be seen in the following figure.

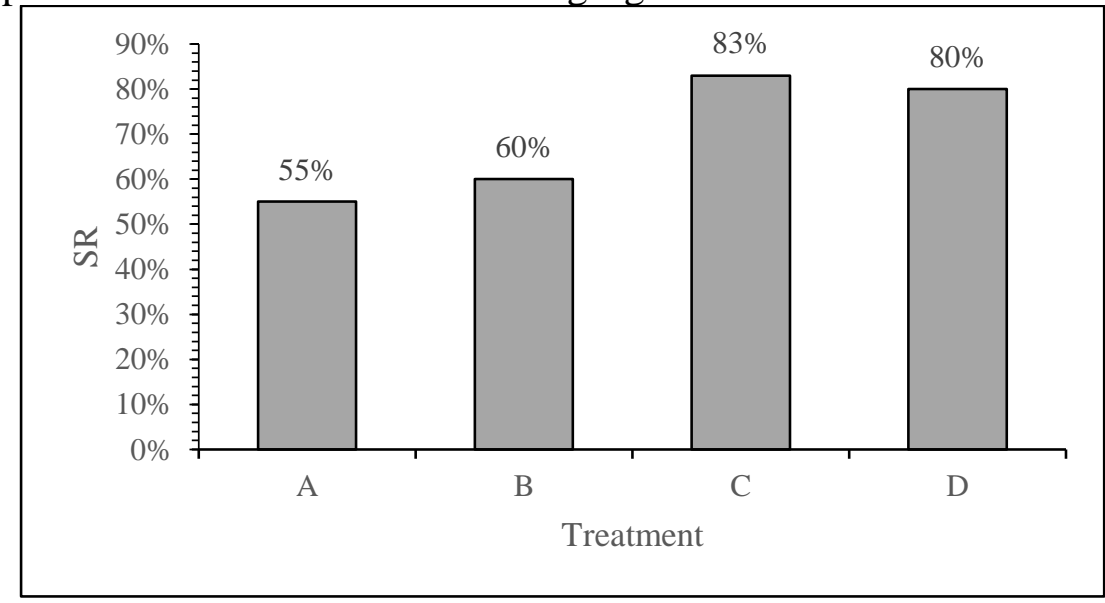

Figure 3. Graph of survival rate results

The graphic above shows that the first and second highest vaname shrimp survival rates were indicated by treatments $C$ and $D$ where the survival rates reached $83 \%$ and $80 \%$, respectively. And the lowest survival rate was indicated by treatment A with a value of only $55 \%$. The high survival rate in treatments $\mathrm{C}$ and $\mathrm{D}$ is thought to be due to the use of sanolife MIC-S probiotics with doses that are in accordance with the needs of the shrimp, so as to prevent high mortality rates in post larvae of vaname shrimp.

The survival rate of vaname shrimp will increase with the use of probiotics containing Bacillus during the rearing period, and probiotics are also able to reduce the growth of vibrio bacteria in the rearing media (Far et al. 2009). Vannamei shrimp rearing with the application of probiotics was able to increase survival reaching $73.53-82.13 \%$ compared to those who did not use probiotics which only reached 67\% (Hasniar et al. 2013). The use of probiotics in vannamei shrimp viewing is able to support the survival of shrimp compared to those without the use of probiotics (Rangka and Mangampa 2012).

The low survival rate in treatments $\mathrm{A}$ and $\mathrm{B}$ was thought to be due to cannibalism and stress in shrimp. The nature of cannibalism can appear when 
shrimp are under stress or due to not getting enough feed from the feed given. Shrimp mortality can also be caused by stress during handling (Sambu et al. 2016). Table 4. The results of the ANOVA test on the survival rate of vaname shrimp.

\begin{tabular}{lrcrlr}
\hline & Sum of Squares & df & Mean Square & F & Sig. \\
\hline Between Groups & 1739.667 & 3 & 579.889 & 5.799 & .021 \\
Within Groups & 800.000 & 8 & 100.000 & & \\
\hline Total & 2539.667 & 11 & & & \\
\hline
\end{tabular}

The results of the ANOVA test in the table indicate that the survival rate of post-vaname shrimp larvae fed on sanolife MIC-S probiotic capsules with a dose of significant effect $(\mathrm{Sig}<0.05)$. then the decision taken is to accept $\mathrm{H} 1$ and reject $\mathrm{H} 0$.

\section{Feed conversion rate}

The results showed that the feed conversion ratio can be seen in the following figure.

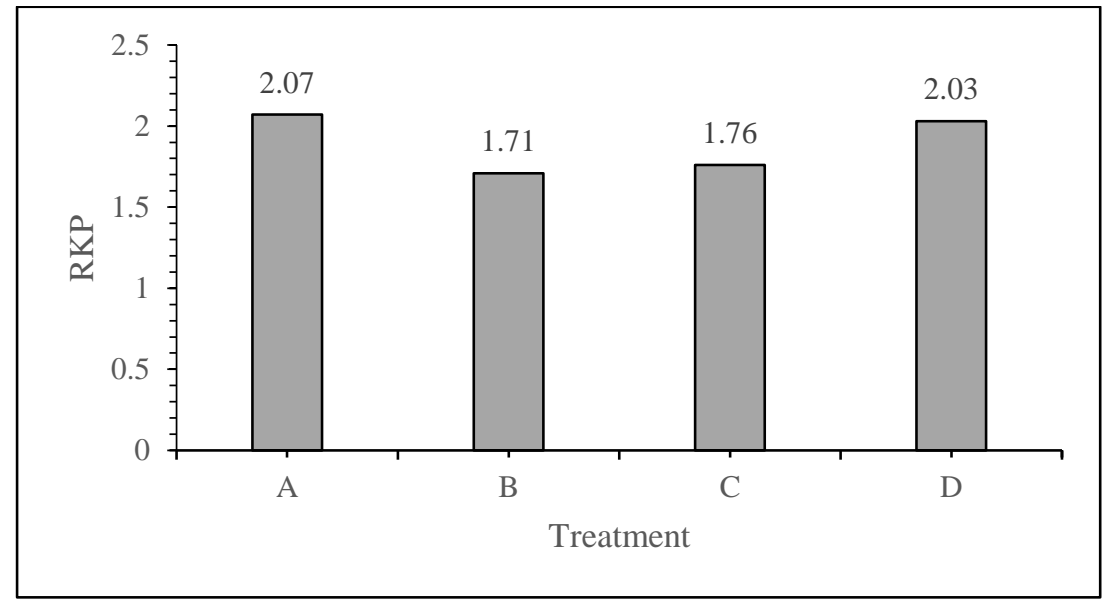

Figure 4. Graph of the results of feed conversion ratio

The graphic above shows that the first and second highest feed conversion ratios were shown by treatments $A$ and $D$ with values of 2.07 and 2.03. while the lowest was seen in treatments B and C, namely 1.71 and 1.76. Based on the results, it can be concluded that the best feed conversion in the use of sanolife MIC-S probiotics with different doses in the feed was indicated by treatments $\mathrm{B}$ and $\mathrm{C}$ with the smallest feed conversion values.

The feed conversion ratio is the ratio between the amount of feed consumed and the weight gain of the shrimp. The value of the feed conversion ratio is inversely proportional to weight gain, so the lower the value, the more efficient the shrimp in utilizing digested food for growth (Mujdiman, 1998). The low feed conversion in treatments $\mathrm{B}$ and $\mathrm{C}$ was possible because the use of probiotic doses in the treatment was very appropriate, so as to increase the digestibility of feed in the intestines of post larval shrimp and contribute to rapid weight gain. The feed conversion value can be influenced by the digestibility of vaname shrimp to the feed given, the use of probiotics containing Bacillus sp. able to provide an important role in producing 
extracellular enzymes so that it can help the digestive process in the shrimp intestine so that it can be absorbed by the body (Ridlo and Subagiyo 2013).

Table 5. ANOVA test results on feed conversion ratio.

\begin{tabular}{lrrrrr}
\hline & Sum of Squares & df & Mean Square & F & Sig. \\
\hline Between Groups & .304 & 3 & .101 & .697 & .579 \\
Within Groups & 1.161 & 8 & .145 & & \\
\hline Total & 1.464 & 11 & & & \\
\hline
\end{tabular}

The results of the ANOVA test in the table above show that the feed conversion ratio rate of post-vaname shrimp larvae fed on sanolife MIC-S probiotic capsules with different doses had no significant effect ( $\mathrm{Sig}>0.05$ ). However, the lowest feed conversion ratio value was in treatment $B$

\section{Feed Efficiency}

The feed efficiency of vaname shrimp fed with the addition of the sanolife MIC-S probiotic with different doses can be seen in the following table.

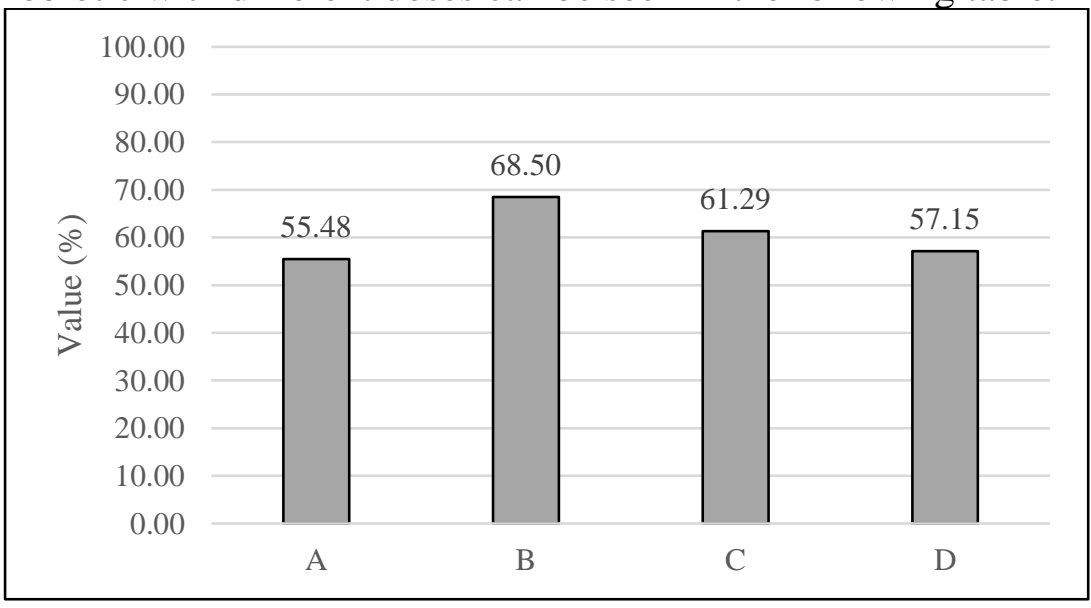

Figure 5. Feed Efficiency Graph

Feed efficiency is the wet weight of fish meat obtained from the rearing period compared to the total weight of dry feed given, where the higher the feed efficiency value, the better the growth rate of fish (Anwar et al. 2016). The feed efficiency graph above shows the highest value, it is shown that the best treatment is shown in treatments B and C, with values of $68.50 \%$ and $61.29 \%$ because they have the highest values.

The high value of feed efficiency in treatment B showed that the use of probiotic doses of $12 \mathrm{~g} / \mathrm{kg}$ of feed gave a positive response to the formation of meat in postlarvae shrimp. The use of probiotics with sufficient doses according to the needs of shrimp larvae so as to help shrimp digestibility of the feed given. The use of the right dose of probiotics will help shrimp organisms in the process of digestion and absorption of the feed given so that it becomes meat (Anwar et al. 2016).

The low feed efficiency in treatments D and A is thought to have a very low post larval response to vaname shrimp. In addition, the temperature and age of the post 
larvae of vaname shrimp can affect growth. The value of feed efficiency is influenced by individual weight, stocking density, age of biota, temperature of rearing media, and feeding management. (Anwar et al. 2016).

Table 6. ANOVA test results on feed efficiency.

\begin{tabular}{lrrrrr}
\hline & Sum of Squares & df & Mean Square & F & Sig. \\
\hline Between Groups & 302.652 & 3 & 100.884 & .824 & .517 \\
Within Groups & 979.756 & 8 & 122.469 & & \\
\hline Total & 1282.408 & 11 & & & \\
\hline
\end{tabular}

Based on the analysis above, it was shown that the efficiency of feed fed with pellets with sanolife MIC-S capsules at different doses had no significant effect (Sig > 0.05). However, treatment B showed the highest feed efficiency value compared to the others.

\section{Water quality}

Water quality measurements were carried out every 7 days in the morning and evening for 30 days of maintenance, the water quality parameters observed during the study were temperature, $\mathrm{DO}, \mathrm{pH}$ and salinity. The results of the range of water quality parameters for white shrimp (Litopenaeus vannamei) during rearing are as follows:

Table 7 . Water quality for vaname shrimp rearing

\begin{tabular}{lcc}
\hline Water Quality & $\begin{array}{c}\text { Range of } \\
\text { Measurement } \\
\text { Results }\end{array}$ & \multicolumn{1}{c}{ Optional Range } \\
\hline Temperature $\left.{ }^{(\circ} \mathrm{C}\right)$ & $27-32$ & $27-32$ (Suprapto, 2005) \\
Salinity (ppt) & $25-30$ & $15-30$ (Abraham and Sasman, 2009) \\
$\mathrm{pH}$ & $8-8.9$ & $6.5-9$ (Wyban dan Sweeny (1991) \\
DO (ppm) & $6.3-9$ & $4-8$ (Wibowo, 2006) \\
\hline
\end{tabular}

Based on the table above, the results of water quality measurements during rearing vaname shrimp fry from post larvae 10 to post larvae 40 or during 30 days of rearing the temperature range of 27-32 oC. According to Suprapto (2005), the temperature of 27-32 oC is considered optimal for vaname shrimp. While Cholik (1988) suggested that vaname shrimp has a high temperature tolerance of 16-32 oC. Salinity values during the study ranged from 25 to $30 \mathrm{ppt}$. These data indicate that the salinity of the water is still within the range that can be tolerated by white vaname shrimp because white vaname shrimp is able to live in a wide salinity (euryhaline). According to the statement of Saoud et al. (2003) that vaname shrimp are able to live in a wide salinity range of $0.5-60 \mathrm{ppt}$.

The $\mathrm{pH}$ during rearing vaname shrimp ranged from 8 to 8.9 which indicated that the $\mathrm{pH}$ of the water was still in the optimum range. According to Wyban and Sweeny (1991) vaname shrimp has a $\mathrm{pH}$ tolerance of 6.5-9. Dissolved oxygen 
during observations ranging from 6.3-9 ppm is still quite feasible. According to Kordi (2012), the growth rate depends on the dissolved oxygen content, because the lack of oxygen in the water can interfere with the life of aquatic biota, including growth. A proper dissolved oxygen level is more than $4 \mathrm{ppm}$.

\section{Conclusion}

The feed profiles that were encapsulated using sanolife MIC-S, protein values, moisture content and ash content for feed were shown by treatment B (probiotic 10 $\mathrm{g} / \mathrm{kg}$ feed). The best fat content was treatment C (probiotic $112 \mathrm{~g} / \mathrm{kg}$ feed) The best crude fiber content was treatment D (probiotic $14 \mathrm{~g} / \mathrm{kg}$ feed). The biological performance of white vaname shrimp showed that the weight growth rate, feed conversion ratio and feed efficiency were best shown by treatment B (probiotic 10 $\mathrm{g} / \mathrm{kg}$ feed) while for length growth and survival was indicated by treatment C (12 g probiotic/kg feed).

\section{References}

[1]. Abraham, T.J. and D. Sasmal. 2009. Influence of Salinity and Management Practices on the Shrimp (Penaeusmonodon) Production and Bacterial Counts of Modified Extensive Brackishwater Ponds. Turkish Journal of Fisheries and Aquatic Sciences., 9:91-98.

[2]. Adilla, D. M., Rusliadi, dan Muliadi. 2019. Pengaruh Penambahan Suplemen Viterna Plus dengan Dosis Yang Berbeda Pada Pakan Terhadap Pertumbuhan Dan Kelangsungan Hidup Udang Vannamei (LitopenaeusVannamei). Jurnal Fakultas Perikanan dan Kelautan, Universitas Riau.

[3]. Adiwijaya. 2003. Budidaya udang vaname (litopenaeus vannamei) system tertutup yang ramah lingkungan. Departemen kelautan dan perikanan balai besar pengembangan budidaya air payau. Jepara.

[4]. Adwijaya. D. dan S. I. Sumatri. 2008. Penerapan Teknologi Budidaya Udang Vaname (L. Vannamei) Semi-intensif pada Lokasi Tambak Salinitas Tinggi. Media budidaya Air Payau Perekayasaan No. 7. 19 hal.

[5]. Adiyodi. K. G. dan Adiyodi. R. G. 1970. Pengendalian Endokrin Reproduksi Pada Decapod Crustacea. Journal Biological Reviews. Vol. 45. No. 2.

[6]. Amri, Khairul dan Iskandar Kanna. 2008. Budidaya Udang Vaname; Secara Semi Intensif, dan Tradisional. Gramedia Pustaka Utama. Jakarta.

[7]. Anwar, S., Arief, M. dan Agustono. 2016. Pengaruh Pemberian Probiotik Komersial Pada Pakan Terhadap Laju Pertumbuhan dan Evesiensi Pakan Udang Vanamei. ( Litopenaeus vannamei). Journal Of Aquaculture and Fish Health. Vol. 5. No. 2.

[8]. Atmomarsono, M. Supito. Mangampa, M. Pitoyo, H. Lideman. Tjahyo, SH. Akudiat, I. Wibowo, H. Ishak, M. Basri, A. Wahyoni, N.T. Latief, S.S. dan Akmal. 2014. Seri Panduan Perikanan Skala Kecil Budidaya U. V Tambak 
Semi Intensif Dengan Instalasi Pengolahan Air Limbah (IPAL). Tim Perikanan WWF - Indonesia.

[9]. Badan Standarisasi Nasional. 2005. Cara Uji Kadar Amonia dengan Spektrofotometer Secara Fenat. SNI 06-6989.30-2005.

[10]. Baneerje, A. V., Banerji, R., Duflo, E., Glennerster, R., Khemani, S. 2010. Kendala Dalam Program Partisipasi: Bukit Evaluasi Acak dalam Pendidikan India. Journal economic policy. Vol. 2. No. 1.

[11]. Basir, B. 2013. Kinerja Probiotik Lactococcuslactis Dalam Saluran Pencernaan Udang Vanamei (Litopenaeus vannamei) Dengan Pemberian Pakan Yang Disuplemen Probiotik Kacang Hijau. Tesis Program Pasca Sarjana, 57 hal.

[12]. Boyd, C.E. 1998. Water Quality Management and Aeration In Shrimp Farming. Fisheries and Allied Aquaculture Departemen Series No. 2. Alabama Agramicultural Experiment Station. Auburn University, Alabama.

[13]. Cholik, F. 1988. Pembangunan Tambak Moderen. Direktorat Jenderal Perikanan Lembaga Penelitian Darat, Bogor.

[14]. Cholik, F., Ateng, G.J., R. P. Purnomo dan Ahmad, Z. 2005. Akuakultur Tumpuan Harapan Masa Depan. Masyarakat Perikanan Nusantara dan Taman Akuarium Air Tawar.

[15]. Corteel, M., Frachi, G., Chiappi, L., Rekecki, A., Wolf, T. DE, dan RomBout, G. 2013. Pengaruh Penggunaan Probiotik Sanolife MIC-F untuk Meningkatkan Ketahanan Larva IkanTerhadap Stres, Histology, dan Mikrobiota Pada Ikan Air Tawar. Book 6th fish \& Shellfish Larviculture Symposium. Ghent University. Belgium.

[16]. Effendie, M. I. 1997. Biologi Perikanan. Yayasan Pustaka Nusantara, Bogor. 163 hal.

[17]. Effendi, H. 2003.Telaah Kualitas Air Bagi Pengelolaan Sumberdaya Dan Lingkungan.Yogyakarta. PT Kanisius.

[18]. Effendi, H. 2000. Telaah Kualitas Air. Jurusan Manajemen Sumberdaya Perairan. Fakultas Perikanan dan Ilmu Kelautan, Institut Pertanian Bogor. Bogor.

[19]. (FAO) Food and Agriculture Organization. 2017. Increased Production of Farmed Shrimp Leads to Improved Interasional Trade. http://www.fao.org/inaction/globefish/market-reports/resourcedetail/en/c/989543. [Diunduh Pada 10 Desember 2020].

[20]. Far, HZ., CRB Saad, H.M. Daud, S.A. Harmin, S. Shakibazadeh. 2009. Effect of Bacillus subtilis on the Growth and Survival Rate of Shrimp (Litopenaeus vannamei). African Journal of Biotechnology. 8: 3369-3376.

[21]. Febrianti, Amran, Y., Irawanti, L. 2010. Pengaruh Penambahan Asupan Kalium Dari Diet Terhadap Penurunan Hipertensi Sostolik Tingkat Sedang Pada Lanjut Usia. Jurnal Kesehatan Masyarakat Nasional. Vol. 5. No. 3.

[22]. Fegan. 2003. Manajemen Yang Sehat Dalam Budidaya Udang. Gold coin Indonesia Specialitis. Jakarta.

[23]. Fernando, E. 2016. Pengaruh Variasi Dosis dan Frekuensi Pemberian Probiotik Pada Pakan Terhadap Pertumbuhan Serta Mortalitas Udang Vaname (Litopenaeus vannamei). Program Sarjana, Universitas Airlangga. 
[24]. Fuller, R. 1989. Probiotics In Man and Animal. JAppl Bacteriol. 66: 365378.

[25]. Gaspersz, V., 1991. Metode Perancangan Percobaan. CV. Armico, Bandung.

[26]. Haliman, R.W. dan D.S. Adijaya. 2005. Udang Vanamei Dalam Pembudidaya dan Prospek Pasar Udang Putih Yang Tahan Penyakit, Penebaran Swadaya, Jakarta.

[27]. Haliman, R.W. \& Adijaya D. 2006. Budidaya Udang Vannamei. Penebar Swadaya. Jakarta. 74 hal.

[28]. Haliman. R.W \& Dian A.S. 2006. Budidaya Udang Vanamei. Swadaya. Jakarta.

[29]. Hameed. A.S.S, M. Anilkumar. M.L.S. Raj \& K. Jayaraman. 1997. Studies on the Phatogenicity of Systemic Ectodermal Mesodermal Baculovirus and its Detection in Shrimp by Immunological Methods. Aquaculture 160. (1998), P:31-45.

[30]. Handayani H dan S.D Hastuti. 2002. Budidaya Perairan. Penerbit Bayu Media dan UMM Press. Malang.

[31]. Hapsari, T., W. Tjahjaningsih., M.A. Almasjahdan H. Pramono. 2016. Aktivitas Enzimatis Bakteri Proteolitik Asal Gastrointestianl Udang Vannamei (Litopenaeus vannamei). Journal of Marine and Coastal Science, 5(3): 109-118.

[32]. Hendrajat, A.E., M. Mangampa., H. Suryanto. 2007. Budidaya Udang Vannamei Pola Tradisional Plus di Kabupaten Maros Sulawesi Selatan. Media Akuakultur, 2(2):4.

[33]. Herdianti, L., Soewardi, K., Hariadi, S. 2015. Efektifitas Penggunaan Bakteri Untuk Perbaikan Kualitas Air Media Budidaya Udang Vaname (Litopenaeus vannamei). Super Intensif. Jurnal Ilmu Pertanian Indonesia (JIPI). Vol. 20. No. 3. ISSN : 0853-4217.

[34]. Heptarina, D., M.A. Supriyadi, I. Mokoginta \& D. Yaniharto. (2010). Pengaruh Pemberian Pakan Dengan Kadar Protein BerbedaTerhadap Pertumbuhan Yuwana Udang Putih (Litopenaeus vannamei).Prosiding Forum Inovasi Teknologi Akuakultur. 6 hal.

[35]. Hu Y., Tan B., Mai K., Ai Q.S., Cheng K. 2008. Growth and Body Composition of Juvenil White Shrimp, Litopenaeus vannamei, Fed Different Rations of Dietary Protein to Energy. Journal Aquaculture Nutrition, $\mathrm{p}: 14$ : 499-506.

[36]. Irianto, A. (2003). Probiotik Akuakultur. Gadjah Mada University Press. Yogyakarta. $125 \mathrm{p}$.

[37]. Jusadi, D., Gandara, E. dan Mokoginta I. 2004. Pengaruh Penambahan Probiotik Bacillus sp. Pada Pakan Komersial Terhadap Konfersi Pakan Dan Pertumbuhan Ikan Patin Pangasius Hypoptalamus. Jurnal Akuakultur Indonesia. Vol. 3. No. 1.

[38]. Kompiang, P., Suprianti, dan Sjofjan. 2004. Pengaruh Suplementasi Bacillus apiaries Terhadap Penampilan Ayam Petelur. Jurnal Ternak dan Veteriner (JITV). Vol. 9. No. 1. ISSN : 0853-7380. 
[39]. Kordi, K.M.G.H. 2012. Jurus Jitu Pengolahan Tambak Budidaya Perikanan Ekonomis. Lily Publisher. Yogyakarta.

[40]. Kurniawan, L.A., Airef. M., Manan. A., dan Nandarwi, D.D. 2016. Pengaruh Pemberian Probiotik Berbeda Pada Pakan Terhadap Retensi Protein dan Retensi Lemah Udang Vaname (Litopenaeus vannamei). Journal Aquaculture \& Fish Health. Vol. 6. No. 1.

[41]. Mudjiman. 1998. Pengukuran Tingkat Kelangsungan Hidup, Laju Pertumbuhan dan Efesiensi Pengguanaan Pakan. Fakultas Perikanan, Institut Pertanian Bogor. Bogor.

[42]. Noermala, I.J. 2012. Pemberian Probiotik dan Simbiotik Untuk Pengendalian Konfeksi Bakteri Vibrio harveyi Pada Udang Vaname (Litopenaeus vannamei). Tesis. Sekolah Pasca Sarjana Institut Pertanian Bogor. Bogor.

[43]. Nune, R. 2016. Pengaruh Pemberian Probiotik Dengan Dosis Yang Berbeda Terhadap Pertumbuhan dan Kelangsungan Hidup Benih Ikan Nila (Oreochromis niloticus) Di Keramba Jaring Apung Danau Limboto. Ung Repository.

[44]. Nayak, S. K. 2010. Probiotik dan Kekebalan: Presfektifkan. Journal Fish \& Shellfish Immunology. Vol. 29. No. 1.

[45]. Rahman, R., Lahming, Fadhilla, R. 2018. Evaluasi Kompenen Gizi Pada Pakan Udang Fermentasi. Jurnal Pendidikan Teknologi Pertanian. Vol. 4.

[46]. Rangka, Nur A., dan Mangampa, M. 2012. Pengaruh Pergiliran Bakteri Probiotik Terhadap Sintasan Dan Produksi Udang Windu Di Tambak Tradisional Di Kecamatan Suppa, Kabupaten Pinrang. Seminar Nasional Tahun IX Hasil Penelitian Perikanan Dan Kelautan.

[47]. Ridlo, A. dan Subagio. 2013. Pertumbuhan Rasio Konversi Pakan dan Kelangsungan Hidup Udang Litopenaeus vannamei Yang Diberi Pakan Dengan Suplementasi Probiotik FOS (FRUKTOOLIGOSAKARIDA). Junrnal Buletin Oseanografi Marina (BULOMA). Vol. 2. No. 4.

[48]. Rosyida, Eka. 2007. Kebutuhan Protein/Asam Amino dan Karbohidrat Bagi Udang-Udang Vanaein: suatu studi literature. Jurnal Biota. Vol. 12. No. 1. ISSN : 0853-8670.

[49]. Saoud, I.P., D.A. David and David and D.B. Rouse. 2003. Suitability Studies of Inland Well Waters For Litopenaeus vannamei Culture. Aquacuture, 217: 373-383.

[50]. Suprapto. 2005.Petunjuk Teknis Budidaya Udang Vannamei (Litopenaeus vannamei) CV Biotirta. Bandar Lampung. 25 hal.

[51]. Suri, R., Putri, B., dan Susanti, O. 2018. Studi Tentang Penggunaan Pakan Komersial Yang Di Campur Dengan Bakteri Bacillus coagulans Terhadap Performa Litopenaeus vannamei. Ejurnal Rekayasa dan Teknologi Budidaya Perairan. Vol. 7. No. 1. e-ISSN: 2597-5315.

[52]. Sunarto dan Sabariah. 2009. Pemberian Pakan Buatan Dengan Dosis Berbeda Terhadap Pertumbuhan Dan Konsumsi Pakan Benih Ikan Semah (Tor douronensis) Dalam Upaya Domestikasi. Jurnal Akuakultur Indonesia. Vol. 8. No. 1. 
[53]. Suyanto, S. R. dan A. Mudjiman. 2001. Tambak Udang. Penebaran Swadaya. Jakarta. Hal 1-165.

[54]. Syadillah, A., Siti, H., dan Muhammad, M. 2020. Pengaruh Penambahan Bakteri (Lactobacillus sp.) Dengan Konsentrasi Berbeda Terhadap Pertumbuhan Udang Vannamei (Litopenaeus vannamei). Jurnal Perikanan, Volume 10. No. 1, 8-12.

[55]. Tahe, S. dan Suwono, H.S. 2011. Pertumbuhan Dan Sintasan Udang Vaname (Litopenaeus vannamei) Dengan Kombinasi Pakan Berbeda Dalam Wadah Terkontrol. J. Ris. Akuakultur. Vol. 6.

[56]. Taqwa, F.H. 2008. Pengaruh Penambahan Kalium Pada Masa Adaptasi Penurunan Salinitas dan Waktu Penggantian Pakan Alami Oleh Pakan Buatan Terhadap Performa Juvenil Udang Vanamei (Litopenaeus vannamei). Tesis. Institut Pertanian Bogor, Bogor.

[57]. Usman, A., dan Rochmady. 2017. Pertumbuhan dan Kelangsungan Hidup Pasca Larva Udang Windu (Panaeusmonodon Fabr.) Melalui Pemberian Probiotik Dengan Dosis Berbeda. Jurnal Akuakultur, Pesisir dan PulauPulau Kecil, EISSN 2598-8298 Vol. 1 No. 1, 19-26.

[58]. Verschuere L, Pombaut G, Sorgeloos P, \&Verstraete W. (2000). Probiotic BacteriaVs Biological Control Agents in Aquaculture. Microbiological and Molucular Biology, 64, 655-671.

[59]. Wahyudin. 2007. SETS Dunia Hewandan Tumbuhan. Arman delta Selaras. Jakarta

[60]. Wang, Y.B.2007. Effect of Probiotics on Growth Performance and digestive enzyme activity of the shrimp penaeusvannamei. J. aquaculture. 269(4): 254-264.

[61]. Watanabe, T., 1988. Fish Nutrition and Mariculture.Departement of aquatic bioscience. Tokyo university of fisheries. JICA.223 pp.

[62]. Wedemeyer. (1996). Growth and Ecology of Fish Populations. London, UK: Academic Press.

[63]. Wibowo, H. 2006. Cara Memilih Benur Vaname Berkualitas. BBAP Situbondo.

[64]. Wyban, J.A and Sweeny, J.N. 1991. Intensive Shrimp Production Technology. The Oceanic Institumakapuu Point. Honolulu, Hawai USA. 158

[65]. Wyk, P. V. (1999). Nutrition and Feeding Of Litopeneus Vanamei In Intensive Culture Systems, Farming Marine Shrimp In Recirculating Fresh Water Systems. Harbor Branch Oceanographic Institution.

[66]. Ziemann, D. A., Walsh, W. A., Saphore, E. G., Fulton-Bennett, K., 1992. Surver Karakteristik Kualitas Air Dari Limbah Aquaculture Hawai. Jurnal Of the World Aquaculture Socity. Vol. 23. No. 3 